\title{
Revitalising embodied community knowledges as leverage for climate change engagement
}

\author{
Laura Donkers ${ }^{1}$ (iD \\ Received: 9 June 2021 / Accepted: 14 February 2022 /Published online: 3 March 2022 \\ (C) The Author(s) 2022
}

\begin{abstract}
Human survival is threatened by climate breakdown and ecological collapse. This levies huge responsibility on society to address how present modes of living have created these problems. Citizens need to learn about the consequences that have been unleashed and find ways to live more sustainably. Yet, the scale of these crises and lack of wisdom to act can be overwhelming, so how will they become more informed and motivated to act? This paper proposes that cultivating communities of practice (Wenger) around low carbon citizenship can help generate discrete engagement strategies that rouse public attention towards changing attitudes and behaviours. To be effective, these engagements need to be relatable, values-oriented, and framed towards the priorities, knowledges, capacities, and lived experiences of the group who each share a passion for a practice and learn collectively how to do it better. Such an approach is explored in the case study, Grow Your Own Community, that sought to engage marginalised communities with decarbonisation activities through the strategic repositioning of their embodied community knowledges (ECK). This community of practice helped to motivate and mobilise local participation by integrating carbon literacy with the situated, practical capacities that already lay within the community. Key findings reveal that revitalising a community's existing body of knowledge to engage people with climate change knowledge creates the conditions for generating community-led mitigative action.
\end{abstract}

Keywords Communities of practice $\cdot$ Climate change engagement $\cdot$ Revitalisation . Leverage $\cdot$ Embodied community knowledges $\cdot$ Community expertise $\cdot$ Marginalised communities

\section{Introduction}

Human actions and activities have been changing the climate and ecology since industrialisation began, leading to unprecedented climate breakdown and ecological collapse (Figueres and Rivett-Carnac 2020). How society attends to these facts will determine the future for humanity. A narrative of 'ecological disaster' can alert the public to the

Laura Donkers

laura.donkers.art@googlemail.com

Outer Hebrides, UK 
risks of not acting (Lowe et al 2006) but the scale and multi-dimensionality of the situation can leave them numb (Norgaard 2011). Even though climate change threatens all aspects of human culture (Adger et al 2013), communities need support to develop climate change awareness (Raymond et al 2021) to help them self-organise and learn for the future (Barnes et al 2020).

Members of communities work collectively for the current and future benefit of those who participate (Lave and Wenger 1991; Wenger 1998; Goodwin 2008). This accumulates as a body of community-based, experiential learning that has evolved via intergenerational relationships and connections to place (Gieser 2008; Given 2008). Named by Lave and Wenger as situated learning, these forms of sited knowledges are the products of systems of activity arising in locally specific social, historical, and cultural contexts as evolved social learnings between people, actions, and environment (1991). The author devised the term embodied community knowledges (hereafter ECK) to classify this form of community expertise that she had observed in the island community where she lived. ECK encompasses different sets of knowledges such as lived experiences, tacit knowledges, and the transference of beneficial knowledges from preceding generations (Lave and Wenger 1991; Wenger 1998) that includes Indigenous ecological knowledges (Berkes et al 2020; Nelson and Shilling 2021). All these knowledges arise from socially situated practices where the activities and their purposes are meaningfully related in the minds of the participants.

Accordingly, the aim of this study is to determine whether a strategy of linking climate change awareness with ECK can activate engagement with carbon reduction activities. In the case study, the author used this ECK framing to underpin the creation of several small, informal learning communities, known as communities of practice (Wenger 1998), hypothesising that their formation could help participants collectively re-orient their existing ECK considering new climate change awareness. Wenger et al.'s 'Seven Principles' model for designing Communities of Practice (2002) will be discussed in relation to their effectiveness as a methodological strategy for engagement.

Previous studies reported that science and politics alone cannot deliver the scalable transformative interventions needed to redirect societal attitudes (Dilling and Moser 2007; Moser et al. 2011; Abson et al 2017). To help citizens learn about the climate crisis and how lifestyle choices increase atmospheric carbon emissions, publicly funded initiatives have been developed. One example in the UK is The Carbon Literacy Project, a 'transformative action programme' that has embedded sustainability knowledge into the workplaces of over 24,000 citizens by teaching climate change and decarbonisation knowledge (2021). Carbon literacy aims to raise awareness of the carbon dioxide costs and impacts of everyday activities, and increase motivation to reduce emissions, individually, communally, and at organisation level. It focuses on the most accessible principles of earth's climate, impacts of climate change, and approaches that can be taken towards adaptation or mitigation.

However, many factors affect how people think about climate change and having more information is not always sufficient to motivate people. As psychologist, Art Markman (2018) explains that the effects of climate change are distant and uncertain, and addressing them involves trading short-term gains for longer-term benefits, which is known as temporal discounting. Greaves frames this in terms of climate change mitigation as the extent to which the 'anticipated benefit of mitigation ...[in] the future reduces the value of that benefit ... occurring now' (2017). This manifests as a propensity to ignore climate change and avoid making the urgent lifestyle changes needed. Thus, to mentally bring the future closer and confront the uncertainty of what climate change might mean long term (Scharmer 2009), it is incredibly important that people are engaged strategically through 
the provision of practical support, as well as information, to encourage them reduce their carbon footprint.

To this end, the Scottish Government's Climate Challenge Fund, in the period 2008-2020, has granted more than £111million to 1150 community-led decarbonisation projects, across Scotland, to grow more local food and reduce car travel, waste, and energy use in homes and community buildings. For thousands of people, this strategy has been successful in making the need for carbon reduction more tangible (Goodwin 2008; Guzman 2009; Morton et al 2011; MacKay and Schmitt 2019), relatable, and framed towards the priorities, knowledges, capacities, and lived experiences of local communities (Whitmarsh et al 2013; Corner et al 2014; Wibeck et al 2019; Jones 2020; Rana et al 2020). Therefore, motivation can be triggered when people understand which of their practices are harmful; what the alternatives are; and, importantly, that significant support to actively engage with those alternatives is provided. Despite these successes, however, people are still hesitant to engage with climate change due to scepticism and uncertainty (Whitmarsh 2011; Morton et al 2011; Markman 2018). As a method to overcome reluctance to engage, this study proposes an additional motivating strategy via the formation of new communities of practice (hereafter CoP/s) (Wenger 1998; Wenger et al 2002; Wenger-Trayner 2015) with the aim of specifically connecting low carbon citizenship with already familiar community practices.

This approach revitalised ECK as leverage for climate change engagement by deploying communities' practical capabilities, integrated social networks, and nature relatedness, to create an epistemological strategy (where reflective thinking increases awareness of personal strengths and learning styles to improve planning, monitoring, and engagement (Whiteley 1969)). Thus, this study presents how the creation of CoPs helped disseminate carbon literacy through practical collective exchange on local food-growing. It makes a novel contribution by identifying how the $\mathrm{CoP}$ model facilitated community transition towards low carbon citizenship by using their mutual linkages (intergenerational and societal bonds, rootedness in particular places, and broad practical capacities and skills base) as nodes of engagement to develop their knowledge, capacity, and motivation towards low carbon citizenship.

The research hypothesis is thus that while visions of ecocide and extinction may invoke paralysis, doubt, and inaction, climate change knowledge that is framed in terms of its relatability to common values and practices can stimulate collective motivation, understanding, and enactive capacity towards adopting decarbonising practices.

\section{Embodied community knowledges as epistemological strategy}

The Grow Your Own Community CoPs were developed to demonstrate how engagement with decarbonisation activities might be leveraged through the revitalisation of relevant community practices. This approach drew on Meadows' concept of 'leverage points' that described the level of impact that different measures can have on changing current systems $(1999,2008)$. The shallower leverage points appeared easier to implement (such as incentives, resource flows) but had less long-term impact; deeper leverage points included the restructuring of rules and institutions, while the most influential (deep) level prompted the changing of mindsets through a process of inner transformation. According to Woiwode et al., this form of deep leverage involves the 're-orientation' of a person's perspective-their 'consciousness, world view, values, beliefs, and 
human-nature connectedness' (2021). Woiwode et al.'s research highlighted dialogue and reflection as important concrete elements that help bring about 'deeper long-term change' towards sustainability and moving from 'ego-system to eco-system awareness' (Scharmer and Kaufer 2015). Issues in identifying and modelling leverage for change in relational social-ecological situations were discussed in Raymond et al., highlighting the difficulty of extracting human actions and experiences from the kinds of situated contexts in which this study also sits. Rather than causing resistance when 'instrumental or intrinsically oriented' decision-making models fail to notice existing human-nature relationships, they recommended 'new forms of processes' that employ other disciplines' reflective and dialogic methods to help develop a theoretical understanding of the interconnected effects present in sited human knowledge linked to relational values (2021).

The author agrees that transforming inner perspectives is a vital component of changing behaviour but a limitation of Raymond et al. and Woiwode et al.'s research is that the focus remains at the theoretical, discursive, and reflective level and not about the actions that urgently need to happen. A key purpose of this paper is thus to highlight that deeper longterm change involves a reorientation of practice and epistemological strategy aiming to use ECK as a community-inclusive method to regenerate cognitive and emotional routes to transition public engagement with mitigating climate change. A report by the Royal Society of New Zealand established this as 'social transitioning' (Sims et al 2016): a complex relationship between cognitive and emotive responses involving assessment of what can be done by citizens to actively reduce their carbon footprint. Wibeck et al. (2019) view that societal transformation towards sustainability necessitates 'new structures, education, and knowledges' to be grafted onto old ways of acting and being so that they resonate with, motivate, and support broader, interrelated participant groups (2019), including the voices, ideas, and visions of young people (Rana et al 2020). Whitmarsh et al. note that civic responses are partly guided by how policy-led initiatives are framed, and whether they promote 'active engagement' or merely 'passive compliance'. They concluded that proposed lifestyle changes that rely too heavily on education and awareness-building are not as effective as methods that also generate emotional investment towards collective moral responsibility (Whitmarsh et al 2013). Therefore, values-oriented and pragmatic approaches are more successful in motivating and engaging communities to take practical mitigative action (O'Brien and Wolf 2010; Whitmarsh et al 2013; Corner et al 2014; West et al 2018, 2020; Jones 2020; Barnes et al 2020; Mattijssen et al 2020), as these are more likely to be 'community-based, participatory, built on priorities, knowledge and capacities of local people' (Reid et al 2009), and 'respect rights, support care and mutuality, strengthening communities and their knowledge systems' (Hill et al 2020). These approaches embrace meaning and significance 'in the specific contexts of living communities' (Guzman 2009) by working with practical forms of knowledge built from their embodied/lived experiences.

This study took the view that ECK is based on 'knowing' as lived experience- -bodies [are] agents of knowledge production' (Wilcox 2009); 'the lived body is at the centre of individual experience' (Merleau-Ponty 1962, 1964); 'embodied knowledge situates intellectual and theoretical insights within the realm of the material world' (Given 2008). Varela et al. recognised the interdependency between both the environment and human experience. They presented cognition as an enacted rather than a representational structure (1991). From this perspective, climate change knowledge is dynamically connected (between mind, body, and environment) through the 'activity of experiencing' (West et al 2020) and, therefore, dependent upon the agency of the body to react, readjust, and selfmodify as a cognitive learning response to the new situation it experiences. 
This research explored whether ECK could be revitalised to leverage climate change engagement by reinvigorating common local food growing practices with the re-oriented purpose of reducing carbon footprint. This approach was relevant to the community's skills and experience, and within their capacity to act. Their new cognisance of local climate change impact was a stimulus for participants to find meaning in their own knowledges and interrelationships (Gieser 2008; Goodwin 2008). Their motivation to take up the desired mitigating activities via their own ECK achieved more than decarbonisation outcomes, arousing enthusiasm to adopt decarbonisation actions as it helped communities help themselves.

The leverage potential of ECK was revitalised because people could draw from practices that were given new relevance in the light of carbon literacy. How laypeople make sense of sustainability policies helps scientists, politicians, and organisations to understand what societal transformation means locally in terms of how it links to everyday life (Wibeck et al 2019). The revitalisation of ECK in the studied community helped highlight its societal value. Face-to-face methods of data gathering facilitated physical interactions between young and elder community members about lifestyles, behaviours, processes, and histories that reinforced and upheld intergenerational knowledge distribution as a valuable system of reciprocal learning for all parties (Comberti et al 2015). The participants found motivation in keeping quantitative records, because as well as providing the evidence of volume grown (for project outcomes records), they could also correlate monetary value to the produce. For the community organisations, the collection of reliable data enabled the project to produce reliable carbon emissions reductions data. Furthermore, the deployment of young residents to harvest baseline data from their own communities, along with respondent's willingness to divulge accurate information, helped towards identifying the contribution already being made towards domestic food production that was not the work of the project but the community's own endeavours. Awareness that the argument for encouraging local food production was already established enabled the sensible targeting of areas for future project direction that included the people with the experience and credibility among their peers towards contributing to project development and delivery. In this way, this approach introduced a new dynamic for the community who were able to contribute as co-managers in their own strategic development.

\section{Methodology}

This research aimed to broaden understanding of the practical capacities and relational values that lie within ECK and leverage them as revitalised forms of knowledge for climate change engagement. Summarised in Table 1, this approach aimed to develop constructive and meaningful climate change mitigation activity in an island-based community.

\subsection{Case study}

The community represented in this research exists across a group of inhabited islands known as the Outer Hebrides, lying off the North-West coast of Scotland (Fig. 1). The total population currently stands at approximately 27,000 islanders living on a landmass of 3071 $\mathrm{km}^{2}$. Of this, the people represented in the study live in townships (networks of approx. 3-10 households) on the islands to the south of Lewis and Harris known as Uist: an area of $892 \mathrm{~km}^{2}$. This chain of islands, including Berneray, North Uist, Benbecula, South Uist, 
Table 1 The research methodology

\begin{tabular}{ll}
\hline Hypothesis & $\begin{array}{l}\text { Climate change knowledge that is locally relatable invigorates and intensifies a commu- } \\
\text { nity's sense of responsibility to act }\end{array}$ \\
\hline Research aim & $\begin{array}{l}\text { To mobilise a community towards climate change engagement through the practical } \\
\text { capacities that lay within their own ECK }\end{array}$ \\
Framing & $\begin{array}{l}\text { Researcher is a social practitioner and long-term resident of the island community, and } \\
\text { thus is considered part of the social system being researched }\end{array}$ \\
Approach & $\begin{array}{l}\text { Communities of practice (CoPs) were setup as creative spaces to draw on communities' } \\
\text { existing capacities and societal connections to inform and promote active engagement } \\
\text { with climate change mitigation }\end{array}$ \\
Questions & $\begin{array}{l}\text { Q1: What mitigative actions can communities readily engage with? } \\
\text { Q2: What motivates and supports communities to engage? }\end{array}$ \\
Participants & $\begin{array}{l}\text { Members of the resident community (incl. crofters, volunteers, young families, elders) } \\
\text { and project stakeholders (community organisations, trust boards, educators) }\end{array}$ \\
Material outputs & $\begin{array}{l}\text { Reclaiming the Knowledge Survey; Uist Growers Almanac; Meeting Ground, 2019 (HDV } \\
\text { video: 16:15 min); Outlier Community Food-Growing Hubs (6); Climate Challenge } \\
\text { Fund Final Project Reports (3) } \\
\text { Eight core messages/key findings reveal how the project revitalised ECK as leverage for } \\
\text { climate change engagement }\end{array}$ \\
Results &
\end{tabular}

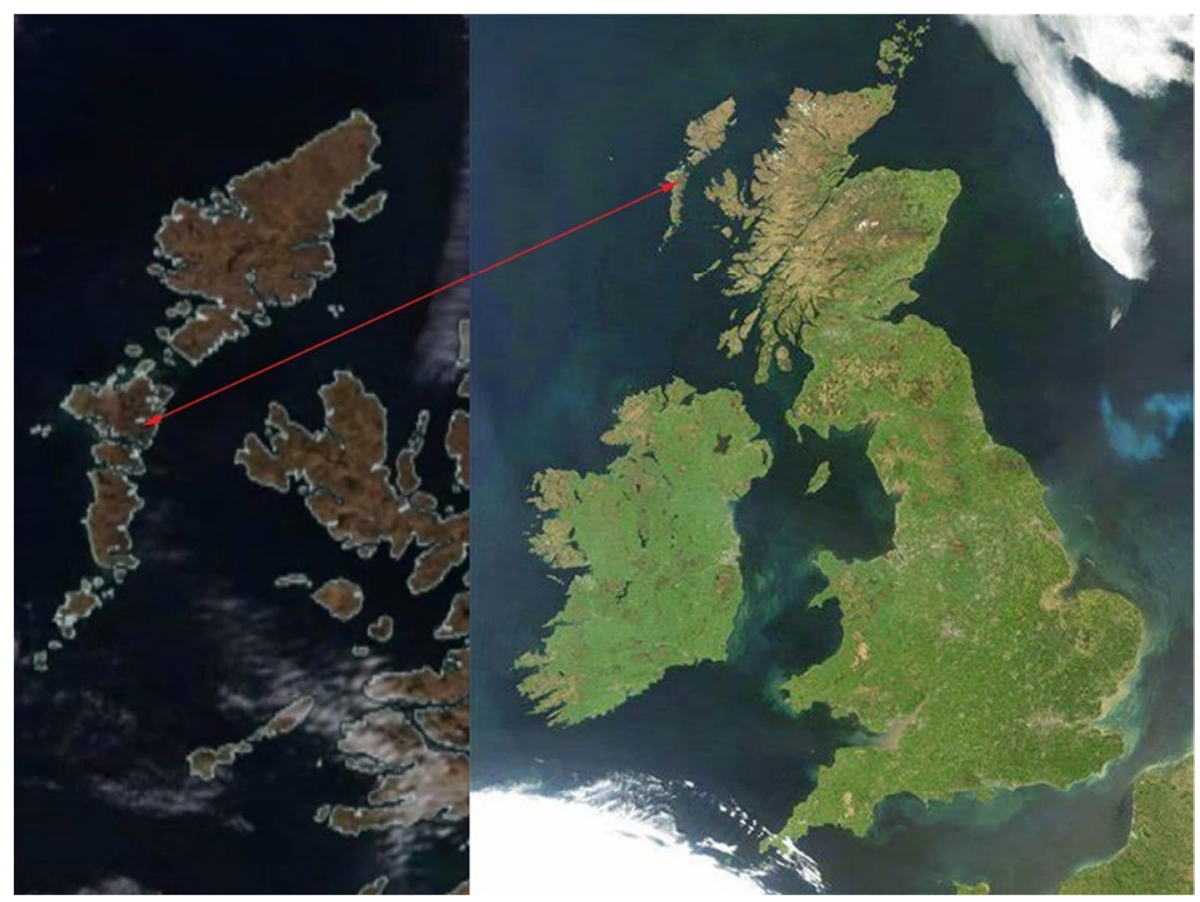

Fig. 1 View of Outer Hebrides 15 Oct 2020. (Image credit: Western Isles Weather from NASA Worldview application (https://worldview.earthdata.nasa.gov/), part of the NASA Earth Observing System Data and Information System (EOSDIS)) 
and Eriskay, has a population of approximately 5000 residents (Comhairle nan Eilean Siar 2020a, b, c). Climatically, the area is dominated by the Gulf Stream, leaving the region comparatively mild, and wet. The poor soils comprise of organic peat with shell sand on the coastal and western fringes. To create fertile arable land, the coastal plains were transformed over centuries through the human activated addition of seaweed (Ritchie 2011). This land form is known as Machair: Scots Gaelic for fertile, low lying grassy plain. Its extensive agricultural management (using small inputs of labour, fertilisers, and capital, relative to the land area being farmed) affords a rare and distinct habitat for a large diversity of wildlife, and represents a long-standing symbiosis between humans and nature (Angus 2009; Angus and Dargie 2009; Lewis et al 2014).

In Uist, climate change is evident in the form of sea level rise, coastal erosion, and rising temperatures causing more frequent/extreme weather events and increasingly flooded land (Angus and Hansom 2006). While major ecological changes are outside of the community's immediate capacity to address, tackling issues around food sovereignty and the benefits of eating seasonal home-grown food can help draw attention towards mitigating some of the carbon emissions linked to production and transport emissions of supermarket bought food. Growing food at the domestic scale for household use remains a habitual activity for islanders, and as such provided a suitable activity to base a decarbonisation project using ECK as a method of engagement.

Communities survived in challenging locations like the Uists because they developed a close, long-term engagement with the environment, by working with and nurturing ecology rather than depleting it (Edwards 2005). The community's collective embodied knowledges encompass lived experience, heritable knowledges, and shared lifeworld beliefs passed on intergenerationally (Gieser 2008; Goodwin 2008). Such knowledges have developed through societal alliances (Goodwin 2008) and in the microcosm of a geographically defined and contained community that is interconnected across the land, sea, and seasons. This community's practical capabilities, including their assets, skills, attitudes, behaviours, lived experiences, knowledges, and agency, have sustained human occupation on the islands for at least 4000 years (Oram and Adderley 2011). In more recent times, community rights to land governance (use and occupation but not ownership) were underwritten by the creation of crofting tenure in a complex process of legislation including the Crofters Holdings (1886) and the Land Settlement (1919). These parliamentary acts, and others, provided townships with the traction and agency to continue to self-organise and learn, validating the collective ethic in regard to a commons and resource-based economy (Hunter 1976; St Martin 2009).

However, these small, geographically widespread communities were still vulnerable to changes wrought by population decline and the impacts of modernity. From mid-1950 onwards, technological advancements drew communities towards a money-based economy through the introduction of domestic water and electricity supplies (House of Commons Debates 1956; Hansard 1964). Further technological progression, seen as 'crucial to economic survival', came in the form of a north-south road network and the development of an internal market leading to more infrastructure and jobs, thereby accelerating islanders' capacity to supply their own individual/family needs (Comhairle nan Eilean Siar 2020a, b, c). Consequently, common understanding of previously pooled assets and materials was altered as both the possibility and necessity to earn money reorganised how people worked and lived together. This resulted in devolved livelihoods, no longer integrated in township collectives, which undermined place-community connectedness (MacKinnon 2018). Nonetheless, despite crofting no longer being the economic driver of land use (MacKinnon 2018; Comhairle nan Eilean Siar 2020a, b, c), crofting townships retain an enduring 
capacity to link people to place, and for the purposes of this research, provide a platform upon which to explore meaningful climate change engagement.

\subsection{Approach}

Framing As a creative social practitioner and long-term resident of the island community, the author is considered part of the social system being researched (Weber and Kurt 2016). The author was employed as Project Leader in the newly created local food-growing project, Local Food for Local People CCF-3812 (Donkers 2016a, b), funded by the Scottish Government's Climate Challenge Fund, and remained as project leader in two subsequent projects Local Food for Local People CCF-4744 (Donkers 2017) and Grow Your Own Community CCF-4968 (Donkers 2018).

Approach The author offers the formation of six communities of practice (CoPs) as local food-growing collectives, developed from the social model of crofting townships, as the key research method. A CoP is a term devised by Wenger (1998) best summarised as 'a group of people who share a passion for a particular practice learning how to do it better by doing it together' (Wenger-Trayner 2015). The CoPs were developed in an initial pilot project Grow Your Own Community (2016-2017) and a subsequent year-long project Grow Your Own Community CCF-4968.

Main project background The initial project had been devised by a partnership of two community organisations: one a community training provider and the other a home care/ community support provider. This project involved the construction of two greenhouses which would produce fresh local vegetables for sale; provide facilities for an accredited horticultural training course to begin; develop community garden/allotment facilities; and could be used as venues for carbon literacy training. These facilities were accessible for communities living near to the main sites, but their centralised location afforded little scope for much of the population to become involved, especially those most geographically marginalised. The term, 'marginalised', identifies the 'vulnerable, oppressed, underrepresented, or undercounted' (Brutschy and Zachary 2014), and is used here to include outlier communities who were geographically disadvantaged, with little or no access to public transport, leaving them isolated from the better serviced population centres where the commissioning organisations were located.

To bridge what the author perceived as a gap in community engagement and to encourage participation from the more marginalised communities, she initiated an interisland survey entitled Reclaiming the Knowledge Data Gathering Project, in recognition of the value and wish to revive interest in local growers' knowledge. All the islands' school children, totaling 750 pupils, were recruited as crowd cartographers to gather data from their home townships with the aim of discovering details of historical and current growing capacity along with related how-to knowledges. In many cases, the children were related to the growers, which helped to arouse widespread attention and produce reliable baseline data, achieving a $21 \%$ survey return rate. The gathered data was subsequently published as a local growers' handbook entitled The Uist Grower's Almanac (Donkers, 2016a, b).

The Grow Your Own Community CoP The Grow Your Own Community CoP evolved from the survey findings where a need arose to help marginalised communities overcome their geographical isolation from the main project outlets through the creation of additional 
small-scale growing sites. Protected growing facilities would be constructed in the form of Polycrubs: a robust type of polytunnel designed in Shetland (Nortenergy 2021). These stormproof facilities were important because they were simple to erect on exposed sites without the need for additional wind or livestock protection, and, due to their insulating properties, were effective at extending the otherwise short growing season. They also afforded a year-round venue offering a socially supportive setting for sharing learning with those who might not have all the skills or experience to know 'how to' grow their own food (Fig. 2).

Issues in accessing available land for consideration as potential growing sites were addressed via expressions of interest (EOI) calling for public nomination of suitable townships. These EOI set the parameters of the ideal site - an area of land at least $15 \times 5 \mathrm{~m}$; access to water supply; located within walking distance of a social housing scheme. The ideal characteristics of the group were also stated (a) an interest in growing food or willingness to learn, and (b) connected to other growers or willingness to connect. A total of 6 groups received support to develop their own CoP. Each site was linked to a social housing scheme and provided with fully constructed growing facilities in the form of a $4 \times 12 \mathrm{~m}$ Polycrub (Nortenergy 2021); all construction costs; internally constructed raised beds, including topsoil and manure; a paid support work for each site to assist with site development; and support the group to work together. Support workers were contracted for one year and were local people known to be successful vegetable growers.

Carbon literacy Accredited Carbon Literacy Training was delivered in workshop form to project staff, support workers, and project participants.

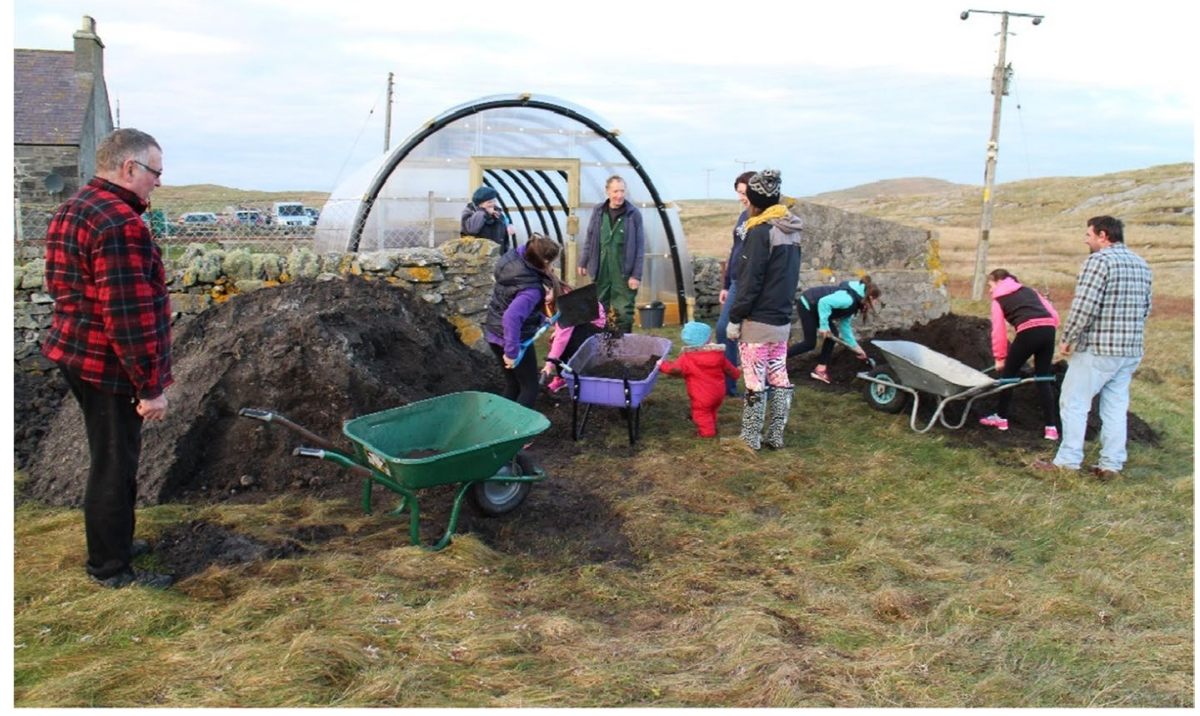

Fig. 2 Berneray Growers Group Open Day 'Bring a shovel and a wheelbarrow' (Dec 2016) (Image credit: L Donkers) 
The 'Meeting Ground' video Meeting Ground was produced in 2019 as a summative finale to the research process (Fig. 3). This presentation aimed to disseminate how each microcommunity had each developed unique responses to the task of collective food growing as a mitigation strategy. The video was screened in a local art gallery for a six-week period in a public exposition of the projects. Meeting Ground communicated how each group had made sense of climate change mitigation through their own capabilities and social networks, expressed in terms of how each group acted together within the context of their own identities, community, knowledge, activity, and experience, thus, publicly presenting community decarbonisation activities in a manner that could be seen and understood as beneficial for their own community.

\subsection{Results}

This study helped to disseminate carbon literacy through the creation of Grow Your Own Community CoPs to help members engage collectively with practical food-growing activity in the context of learning about the climate change. The new food-growing communities proactively helped to shape project development, outcomes, and meaning-making around climate change mitigation (Fig. 4). Participants contributed to managing their groups which ensured that their own ECK was included as a strategic part of project development. Each growers' groups had different structures according to the location or demographic, for example one attracted young families who are interested in the social aspects of growing; another was mostly males, who were interested in building more growing spaces to increase the potential production on the site; another attracted a broad intergenerational group to family food growing; and another attracted mostly incomers to the community, they had been interested in accessing growing space but also the social aspect of getting to know one another.

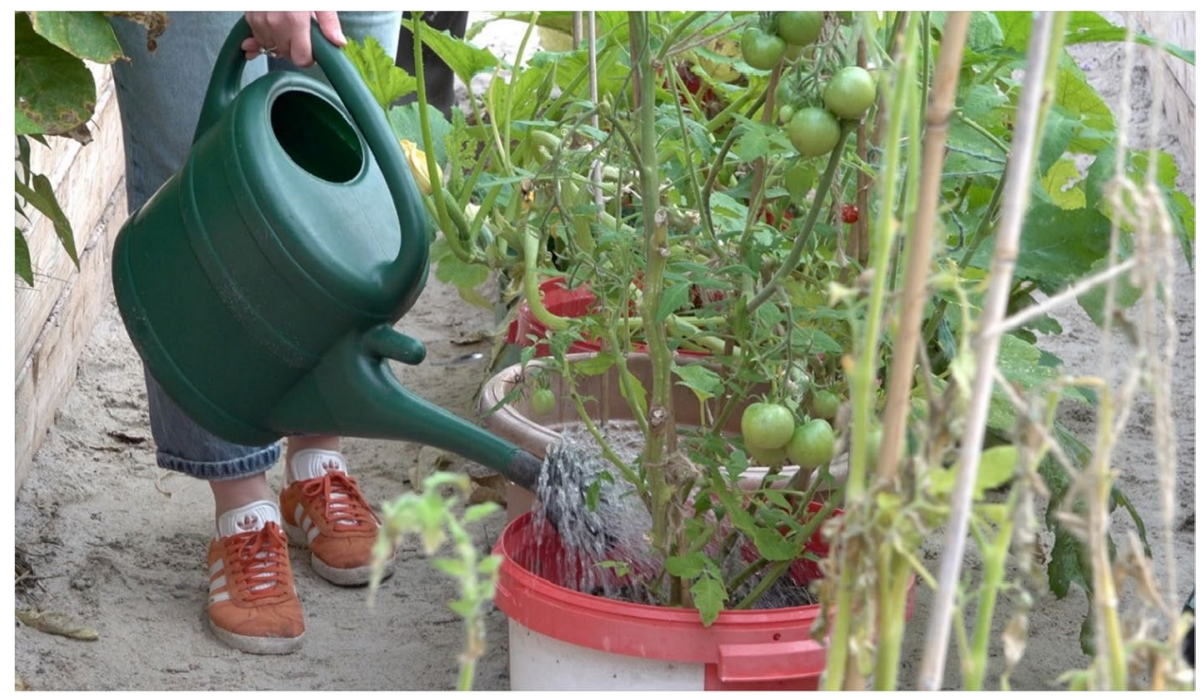

Fig. 3 Meeting Ground, 2019—Video Still (Image credit: L Donkers) 


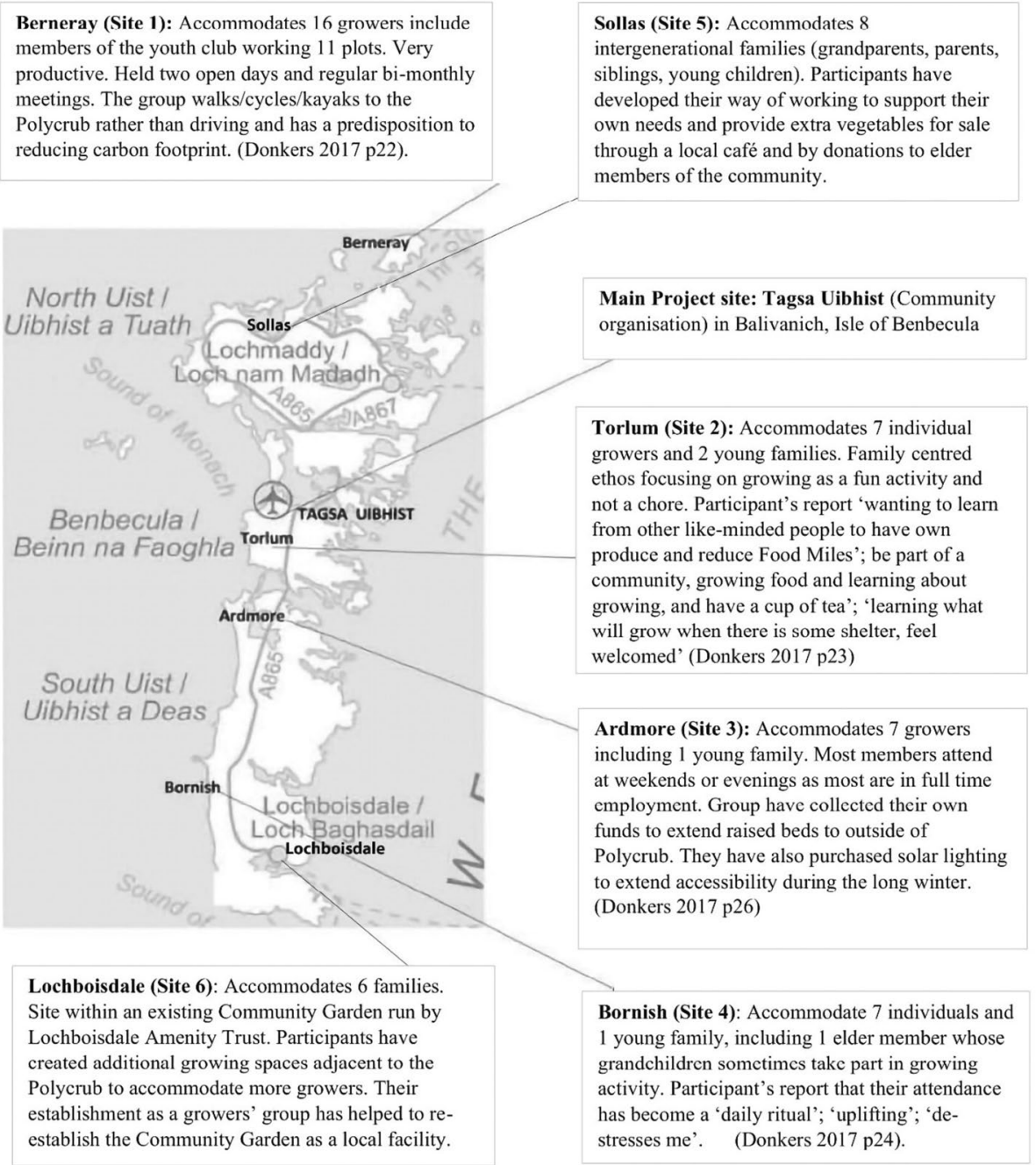

Fig. 4 Map showing locations of Polycrubs (Image Credit: LDonkers)

Carbon literacy Each group's support worker was tasked with developing carbon literacy in a way that aligned with the dynamics of their group and to disseminate carbon literacy more widely. They reported on their experiences of discussing climate change with their groups:

I attended the session on Carbon Literacy training, it has made me more aware of the issues that affect our ever day lives, and we support each other on matters relating to the crub for example the use of seaweed, and if possible, to avoid excess use of pesticides.

We have had some conversations about climate change and people now take note of the distance some of the food we eat travels, so we hope to be able to supply our 
group with enough veg and be able to share it with some of the elderly in our community

The Carbon literacy training was useful. The group is already environmentally aware, and the training made it easier to turn the conversation to environmental issues.

Climate conversations have usually arisen spontaneously, during conversation in the Polycrub. Some conversations were on a global level focusing on ice caps melting and on political effects of changing weather patterns and food availability leading to mass migration, and on a local level; changes to the coastline, increasing storms. Everyone feels a bit powerless in the face of the global situation but then it gets talked about what we can do on a personal level. We talk about food miles and growing our own food where we can but also about other slight changes we can make, like walking to nearby places, rather than take the car and changing to LED bulbs.

\subsection{Core messages and key findings (Table 2, Fig. 5)}

\section{Discussion}

In this section, the author discusses Wenger et al.'s revitalisation model 'designing for 'Aliveness', (2002) to reflect on how the CoP helped drive community engagement with food growing as a decarbonisation strategy.

\subsection{Seven principles for cultivating communities of practice}

Wenger et al. state that 'communities, unlike teams ... need to invite the interaction that makes them alive'. This arises in the functions they perform and by being open to participation in a publicly visible format that also has scope for privacy. A CoP needs scope to develop organically and respond in a dynamic way to what it encounters in the natural process of its evolution, while also delivering on the goals that instigated its creation (2002). Wenger et al. set out seven principles for designing a community that is 'natural, spontaneous, self-directed' (2002) and yet delivers what the organisation requires of it, which in the context of this study was to engage with carbon literacy.

\subsubsection{Design for evolution-generating an environment where the group can thrive}

Ideas for the Polycrub CoPs were developed from the social model of crofting townships (human settlements of 3-10 households) that dot the landscape of the Outer Hebrides. Township dwelling evolved over generations through building connections and adapting to changes. Evolution was fundamental to islanders' identities that have thrived in an ongoing process of joining together and sharing responsibility for collective prosperity. This is the process of situated learning that Lave and Wenger (1991) relate to the social situation, where learning is supported by social engagement to give context for its application. Members of these township communities have learned, through 'hands-on' participation, how to do the necessary tasks in the place where 'agent, activity, and the world mutually 


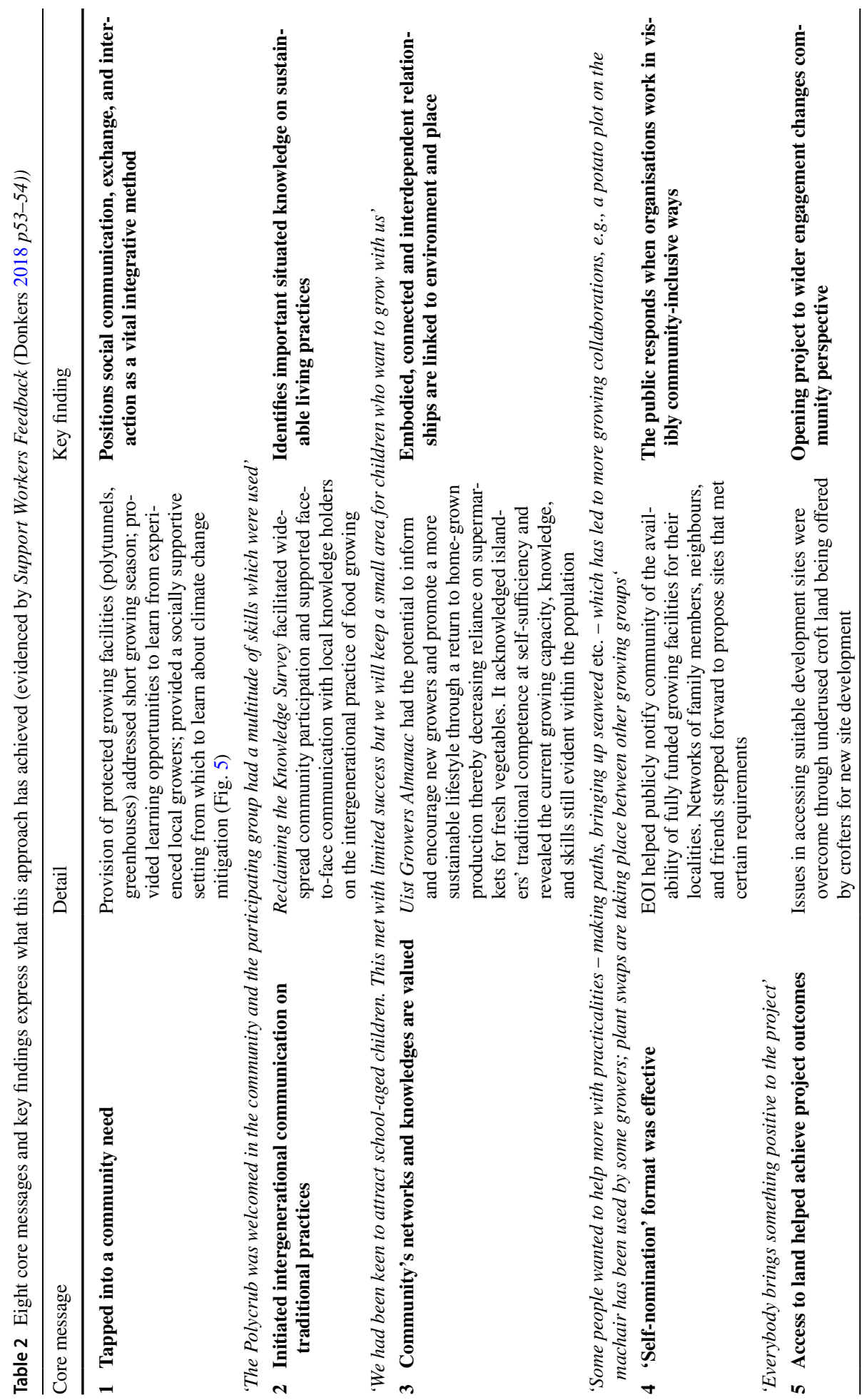




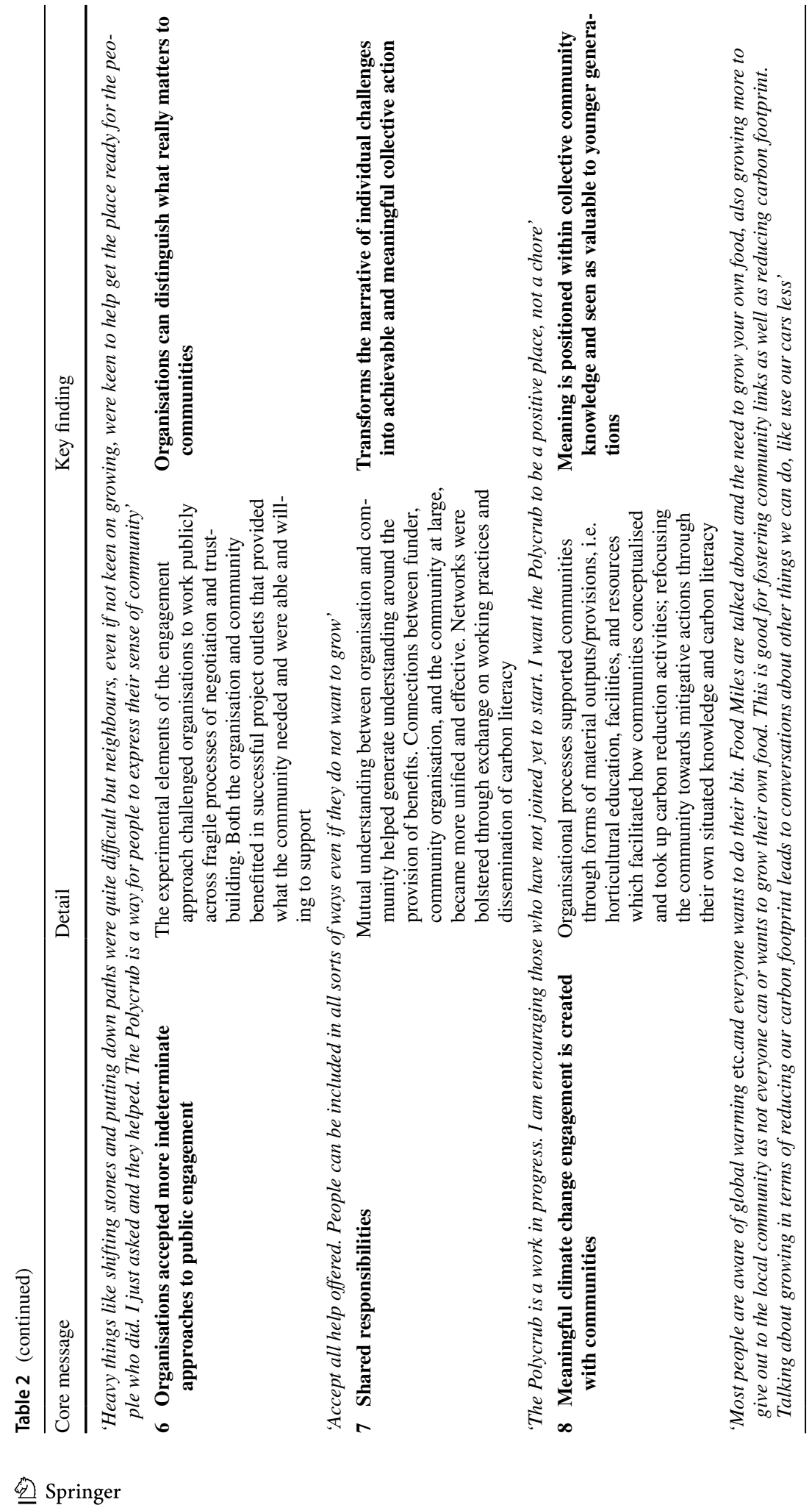




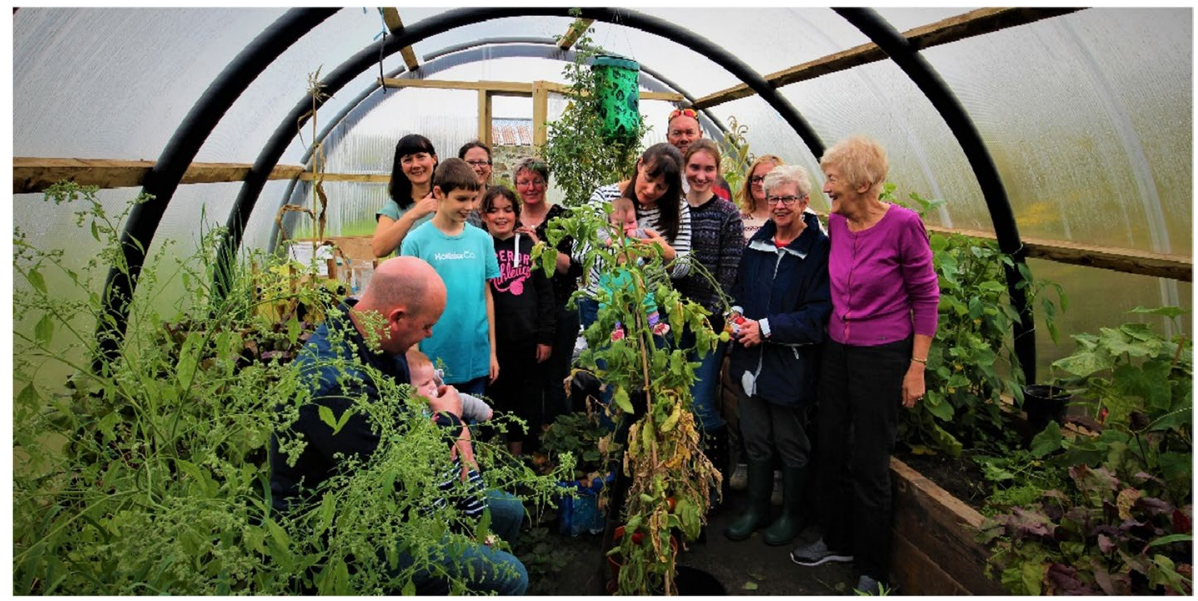

Fig. 5 Sollas Growers Group Open Day (June 2019) (Image credit: L Donkers)

constitute each other' (1991). Therefore, the vital connections around a network of interest were already established.

\subsubsection{Open dialogues between inside and outside perspectives-'effective community design is built on the collective experience of community members'}

The Reclaiming the Knowledge Survey enabled face-to-face intergenerational communication around the heritage and activity of food growing with family members, extended families, neighbours, and other residents. These aspects informed project development and identified its local relevance by being connected to community issues and led from insider perspectives. This process also highlighted the value of local knowledge and the skills of growers and the sharing of this knowledge via the experienced support worker. However, it also generated new possibilities, such as via the introduction of Polycrubs; the activation method through EOIs; and the responsiveness of the local housing association who had assisted in providing a suitable site. These aspects all helped to introduce novel approaches that helped the CoPs to develop. 'Designing for Aliveness' requires that the community has sufficient resources (time, space, support) and can be stimulated into action through information brought in from outside the community to underpin the purpose and value of the CoP, such as through carbon literacy training.

\subsubsection{Invite diverse levels of participation-people participate for varied reasons and at interchanging levels}

Wenger et al. (2002) identify three levels of participation-the core members (the group leaders who are also growers); the active members (the rest of the growers); the peripheral members (the supporters); the peripheral community (the neighbours). With the social network of family members, neighbours, and friends that are found in small township communities, these roles are interchangeable according to the stages of the project. As the CoPs developed, they drew on connections that extended into the 'peripheral community'. The generosity the participants were afforded, such as in use of machinery or supply of organic 
materials, were acts of solidarity as well as opportunities for the wider community to find out what the project was all about. Even discussions with neighbours, which at times were fraught, helped generate an ethos of openness to 'peripheral members' that helped establish the CoPs in the community.

\subsubsection{Develop both public and private community spaces-dynamic communities connect in public meetings and private one-to-one engagements}

Problems of site access were unlocked through extending dialogues out-with the organisation and into the community, particularly around the needs of marginalised groups. Within the confines of the Polycrub, there were often arguments about space and the imposition of vegetation covering another's plot but once resolved, these helped cultivate a sense of respect for another's territory. Once working relationships and practices developed, individual voices around preferences and proposing innovative ideas started to emerge: 'the collective character of knowledge does not mean that individuals do not count ... the best communities' welcome strong personalities and encourage disagreements and debates.' (Wenger et al. 2002).

\subsubsection{Focus on value-communities can deliver value to organisations}

The CoP grew food as a collective and, due to events and social media, quickly became publicly visible, creating an expectation around its value locally. This caused its own challenges with new individuals requesting to join the $\mathrm{CoP}$, but it also highlighted the benefits it was bringing in relation to resolving some of the needs of the community, particularly around social isolation, physical activity, and healthy eating. These manifested in 'small, everyday interactions' with community members, group members, and visitors to the sites sharing informal discussions about the benefits of growing, healthy eating, and being social.

\subsubsection{Combine familiarity and excitement—creating 'neutral places' that people can engage with for their own benefit}

The CoPs began with a network of interconnectivity around growing food among people who knew of each other but were not necessarily friends. They created something new by building on their mutual connections, interests, and desire to work together to improve their collective situation. The support workers weres key here in proposing engaging activities, such as open days, to extend the links to the wider community, so that each CoP became 'a "place" to develop the relationships they needed, in order to be well connected as well as generate excitement' (Wenger et al. 2002).

\subsubsection{Create a rhythm for the community-a 'tempo of interaction'}

The CoPs helped to develop relationships across the wider community through a structure of regular open days that became a feature in the island's social calendar. This was initiated from the beginning of the project, when the first growers' group devised a 'Bring a Shovel and a Wheelbarrow' Open Day (Fig 2) to show their neighbours what they were doing and enlist their support to move topsoil into the raised beds. They also held regular meetings to discuss seasonal activities as well as address problems and discuss requests for new 
membership, also keeping a waiting list for interested parties who could take over plots next season as others vacated them.

\subsection{The intentional and unintentional outcomes of this process}

The CoPs developed their own capabilities in terms of how they acted together, felt in charge of their own legacy, and within the context of their own territory. This helped bolster associations between the CoPs and peripheral communities through exchanges around working practices, and sharing of materials and produce. From a decarbonisation perspective, each $\mathrm{CoP}$ produced more than just recordable data to calculate $\mathrm{CO} 2$ savings, by weighing vegetables; for example, it also produced community benefits. These were seen in the face-to-face engagements between newcomers, young, and elder community members about sustainable lifestyles and low-carbon behaviours, which helped reinforce intergenerational knowledge distribution as a valuable system of mutual learning. These highlighted existing community practices and thus included the very people with the experience and credibility among their peers who could best contribute towards successful growing outcomes. This inclusive framework enabled the CoP members to become co-managers in their own strategic development.

\subsection{The implications for working with organisations and the public}

As project leader, the author adopted a 'cultivating' rather than 'managerial' position to support the informal, self-organising structure of the CoPs by appreciating growers' individual needs within the collective space. This developed mutual understanding around the provision of benefits between the commissioning organisations and the CoPs. This was most visible in meetings between the funder, community organisation, and the community, particularly when they took place at the Polycrubs. The experimental nature of this approach challenged organisations to work with the fragile processes of negotiation and trust-building in a publicly visible way. The organisation gave the CoPs what they needed and the CoPs reciprocated by contributing to the project's carbon emissions reductions targets through weighing all food grown, committing to composting all food and garden waste, and taking part in carbon literacy training.

For the organisation, the CoPs became both an effective community engagement tool and a reproducible model. The CoPs also showed the peripheral community what can be done when individuals come together to practice what they are passionate about. Wenger et al. identify that 'cultivating' rather than 'managing' the community brings out their internal direction and character: "' [a]live' communities reflect on and redesign elements of themselves throughout their existence' (2002).

\section{Conclusion}

Societal transformation can be achieved if new knowledge is framed in terms of existing practical knowledges and through multivocality, which helps arouse attention and reinvigorate community connections. This paper argued that the presented case study demonstrated an approach to re-orienting perspective on climate change by motivating a community to adopt mitigative activity through strategic use of their own ECK. This was achieved through the development of Polycrub CoPs, which became models of 
resilience and cohesion with members gaining a clearer sense of their own 'social capital'. Carbon literacy workshops delivered vital climate change information and opportunities to discuss its day-to-day impacts.

The creation of the CoPs aligned strategically with local organisations and national funding bodies who provided the vital support (funding, expertise) that communities need if they are to adapt their current reliance on supermarkets to more sustainable options. However, the CoPs were successful because they drew from their own sources of local leadership and capabilities. The individuals who stepped forward to offer available land or to take up the roles of support workers emerged from the marginalised communities themselves, which was an unusual situation for all parties. These individuals brought their local identities and networks to the CoPs and without them the same range of participants and peripheral supporters would not have been easily accessed.

Such groups are not usually included in discussions about how communities might best contribute to climate change mitigation and adaptation plans, or what communityled projects could look like. This poses a real and present problem for public engagement with the threats to individual and collective futures that climate change poses. Agreeing the need for grassroots leaders to come forward should be an early priority for local and national stakeholders if genuine public engagement is to be sought.

It is beyond the scope of this observational study to decipher scientifically because of this initiative where transformative changes may have occurred in the community. However, it seems fair to record that the community has experienced a shift in some of their practices, with a renewed sense of value and purpose informing a return to the process of communal food growing as an informed mitigative activity that also delivers a social benefit. The network of community Polycrubs continues to be well used with waiting lists for new growers held at several sites. Additionally, their existence would appear to have influenced a wider return to domestic food growing as since the projects ended over two hundred more have been constructed across the islands of the Outer Hebrides.

The set of eight core messages and key findings highlights the contextual factors and mechanisms, which can influence the outcome of community engagement interventions. The author offers this as a guide for other organisations. While the principles are based on a specific island community, the author considers that they could be adapted to the contexts of other small communities, in rural or urban locations, as the key connecting factor is found in the communities themselves. Organisations could use this approach to motivate and support citizens so they can take some share in developing meaningful mitigative actions for themselves.

This research reveals that the revitalisation of embodied community knowledges can provide a basis from which to develop understanding of climate and ecological breakdown. Key findings reveal that by working with community, connecting to place, and drawing from ECK perspectives, community members can be effectively motivated to become attentive, vocal, and active towards taking mitigative climate change actions.

Supplementary Information The online version contains supplementary material available at https://doi. org/10.1007/s10584-022-03327-w.

Acknowledgements I would like to express my appreciation to members of the island community represented in this study, who supported and encouraged my approach to project design and delivery during the practice phase of research. I would like to acknowledge the guidance and supervision provided by academic supervisors Professor Mary Modeen, Dr Iain Biggs, and Professor Ioan Fazey, in the period of research that this paper draws from. 
Author contribution This is a single-authored manuscript where the conception, design, data collection, and writing were carried out by the author only.

Funding This research paper draws from the author's $\mathrm{PhD}$ research which received full studentship funding from the Scottish Graduate School of Arts \& Humanities/Arts \& Humanities Research Council Doctoral Training Partnership in Creative Economies.

Data availability A series of End of Project Reports for the Scottish Government's Climate Challenge Fund are available as online publications written by author (links in reference section).

\section{Declarations}

Ethics approval Research Project approval was provided by University of Dundee School of Art \& Design Research Ethics Committee on 4 September 2018 (Application Number SAD_18_RPG0120).

Consent to participate Consent to participate was given by all research participants.

Consent for publication All participants gave consent for this research to be published.

Conflict of interest The author declares no competing interests.

Open Access This article is licensed under a Creative Commons Attribution 4.0 International License, which permits use, sharing, adaptation, distribution and reproduction in any medium or format, as long as you give appropriate credit to the original author(s) and the source, provide a link to the Creative Commons licence, and indicate if changes were made. The images or other third party material in this article are included in the article's Creative Commons licence, unless indicated otherwise in a credit line to the material. If material is not included in the article's Creative Commons licence and your intended use is not permitted by statutory regulation or exceeds the permitted use, you will need to obtain permission directly from the copyright holder. To view a copy of this licence, visit http://creativecommons.org/licenses/by/4.0/.

\section{References}

Abson DJ, Fischer J, Leventon J et al (2017) Leverage points for sustainability transformation. Ambio 46:30-39. https://doi.org/10.1007/s13280-016-0800-y

Adger WN, Barnett J, Brown K, Marshall N, O'Brien K (2013) Cultural dimensions of climate change impacts and adaptation. Nat Climate Change 3(2):112-117. https://doi.org/10.1038/nclimate1666

Angus S (2009) Dé tha cearr air a'mhachaire? Biodiversity issues for Scottish machair: an initial appraisal. Glasgow Naturalist, Supplement. Machair Conservation: Successes and Challenges. 25:53-62http:// www.glasgownaturalhistory.org.uk/machair/de_tha_cearr.pdf

Angus S, Dargie T (2009) The UK Machair Habitat Action Plan: progress and problems. Bot J Scotl 54(1):63-74. https://doi.org/10.1080/03746600208685029

Angus S, Hansom J D (2006) Tir a' Mhachair, Tir nan Loch? Climate change scenarios for Scottish Machair systems: a wetter future. In: Angus S. Ritchie, W. (eds.) Sand Dune Machair 4. Aberdeen Institute for Coastal Science and Management: Aberdeen: 29-36. https://www.semanticscholar.org/paper/Tira\%E2\% 80\%99-Mhachair\%2C-Tir-nan-Loch-Climate-change-for-a-Angus-Hansom/f84bfc772fd68e8 7ed22807df3c769105b01dc6a?p2df

Barnes ML, Wang P, Cinner JE, Graham NAJ, Gurrero AM, Jasny L, Lau J, Sutclife SR, Zamborain-Mason J (2020) Social determinants of adaptive and transformative responses to climate change. Nat Clim Chang. https://doi.org/10.1038/s41558-020-0871-4

Berkes F, Colding J, Folke C (2020) Rediscovery of traditional ecological knowledge as an adaptive method. Ecol Appl 5(10):1251-1252. https://doi.org/10.1890/1051-0761(2000)010[1251:ROTEKA]2.0.CO;2

Brutschy S, Zachary D (2014) Marginalized communities. In: Michalos A.C. (eds) Encyclopedia of Quality of Life and Well-Being Research. Springer, Dordrecht: 3771-3776 https://link.springer.com/refer enceworkentry/10.1007\%2F978-94-007-0753-5_1725 in https://doi.org/10.1007/978-94-007-0753-5 
Comberti C, Thornton TF, de Echeverria VW, Patterson T (2015) Ecosystem services or services to ecosystems? Valuing cultivation and reciprocal relationships between humans and ecosystems. Glob Environ Chang 34:247-262. https://doi.org/10.1016/j.gloenvcha.2015.07.007

Comhairle nan Eilean Siar (2020a) Agriculture and crofting. https://www.cne-siar.gov.uk/strategy-perfo rmance-and-research/outer-hebrides-factfile/economy/agriculture-and-crofting/. Accessed 22 Feb 2022

Comhairle nan Eilean Siar (2020b) Bridges, causeways, and ferries. https://www.cne-siar.gov.uk/roadstravel-and-parking/bridges-causeways-and-ferries/. Accessed 22 Feb 2022

Comhairle nan Eilean Siar (2020c) Island populations. https://www.cne-siar.gov.uk/strategy-performanceand-research/outer-hebrides-factfile/population/island-populations/. Accessed 22 Feb 2022

Corner A, Markowitzn E, Pidgeon N (2014) Public engagement with climate change: the role of human values. Wire's Clim Chang 5(3):411-422. https://doi.org/10.1002/wcc.269

Crofters Holdings (Scotland) Act 1886. https://www.legislation.gov.uk/ukpga/Vict/49-50/29/conte nts. Accessed 22 Feb 2022

De Meuse KP, Dai G, Hallenbeck GS (2010) The many faces of learning agility. Mid Winter Conference of Consulting Psychology. https://studylib.net/doc/18031184/the-many-faces-of-learning-agility. Accessed 22 Feb 2022

Dilling L, Moser SC (2007) Introduction. In: Moser SC, Dilling L (eds) Creating a Climate for Change: Communicating Climate Change and Facilitating Social Change. Cambridge University Press, Cambridge, UK, pp 1-27

Donkers L (2016a) Local food for local people CCF-3812 final report. Unpublished report available as supplementary information

Donkers L (2016b)Uist Growers Almanac: the natural way to grow. Self-published handbook available as supplementary information

Donkers L (2017) Final Report Local Food for Local People CCF-4744. Unpublished report available as supplementary information

Donkers L (2018) Final Report Grow Your Own Community CCF-4968. Unpublished report available as supplementary information

Donkers L (2019) Meeting ground, 2019 (HDV; 16:15). Available as supplementary information https:// discovery.dundee.ac.uk/en/publications/film-meeting-ground

Edwards JK, Whittington G, Ritchie W (2005) The possible role of humans in the early stages of machair evolution: palaeonenvironmental investigations in the Outer Hebrides. Scotl J Archaeol Sci 32(3):435449. https://doi.org/10.1016/j.jas.2004.09.011

Figueres C and Rivett-Carnac T (2020) The future we choose. Manilla Press UK

Gallay E, Marckini-Polk L, Schroeder B, Flanagan C (2016) Place-based stewardship education: nurturing aspirations to protect the rural commons. Peabody J Educ 91(2):155-217. https://doi.org/10.1080/ 0161956X.2016.1151736

Gieser T (2008) Embodiment, emotion and empathy: a phenomenological approach to apprenticeship learning. Anthropol Theory, SAGE Publ. https://doi.org/10.1177/1463499608093816

Given L M (2008) Embodied knowledge in The SAGE Encyclopaedia of Qualitative Research Methods (vols. 1-0). SAGE Publications, Inc., Thousand Oakshttps://doi.org/10.4135/9781412963909.n127

Goodwin C (2008) The co-operative, transformative organization of human action and knowledge. J Pragmat 46(1):8-23. https://doi.org/10.1016/j.pragma.2012.09.003

Greaves H (2017) Discounting for public policy: a survey. Econ Philos 33:391-439. https://doi.org/10.1017/ S0266267117000062

Guzman G (2009) What is practical knowledge? J Knowl Manag 13(4):86-98. https://doi.org/10.1108/ 13673270910971851

Hill R, Admen C, Alangui WV, Molnar Z, Aumeeruddy-Thomas Y, Bridgewater P et al (2020) Working with indigenous, local and scientific knowledge in assessments of nature and nature's linkages with people. Curr Opin Environ Sustain 43:8-20. https://doi.org/10.1016/j.cosust.2019.12.006

Hansard (1964) North Uist and Barra (Electricity Supply). https://api.parliament.uk/historic-hansard/ commons/1964/jan/22/north-uist-and-barra-electricity-supply. Accessed 22 Feb 2022

House of Commons Debates (1956) Electricity supply, outer hebrides oral answers to questions - Scotland - in the House of Commons at 12:00 am on 20th November 1956. https://www.theyworkforyou.com/ debates/?id=1956-11-20a.1523.5

Hunter J (1976) The making of the crofting community. Edinburgh, John Donald

Jones O (2020) Pragmatism, anti-representational theory, and local methods for critical-creative ecological action. Wills J, Lake R (eds) The power of pragmatism: knowledge production and social enquiry. Manchester University Press

Land Settlement (Scotland) Act 1919. https://www.legislation.gov.uk/ukpga/Geo5/9-10/97/contents. Accessed 22 Feb 2022 
Lave J, Wenger E (1991) Situated learning: legitimate peripheral participation. Cambridge University Press

Lewis RJ, Pakeman RJ, Angus S, Marrs RH (2014) Using compositional and functional indicators for biodiversity conservation monitoring of semi-natural grasslands in Scotland. Biol Cons 175:82-93. https:// doi.org/10.1016/j.biocon.2014.04.018

Lowe T, Brown K, Dessai S, de Franca Doria M, Haynes K, Vincent K (2006) Does tomorrow ever come? Disaster narrative and public perceptions of climate change. Public Underst Sci 15(4):435-457. https:// doi.org/10.1177/0963662506063796

MacKay CML, Schmitt T (2019) Do people who feel more connected to nature do more to protect it? MetaAnalysis J Environ Psychol 65:101323. https://doi.org/10.1016/j.jenvp.2019.101323

MacKinnon I (2018) 'Decommonising the mind': historical impacts of British imperialism on indigenous tenure systems and self-understanding in the Highlands and Islands of Scotland. Int J Common 12(1):278-300

Markman A (2018) Why people aren't motivated to address climate change. Harvard Bus Rev. https://hbr. org/2018/10/why-people-arent-motivated-to-address-climate-change. Accessed 22 Feb 2022

Mattijssen TJM, Ganzevoort W, van den Born RJG, Arts BJM, Breman BC, Buijs AE, van Dam RI, Elands BHM, de Groot WT, Knippenberg LWJ (2020) Relational values of nature: leverage points for nature policy in Europe. Ecosyst People 16(1):402-410. https://doi.org/10.1080/26395916.2020.1848926

Meadows DH (1999) Leverage points: places to intervene in a system. The Sustainability Institute, Hartland. http://www.donellameadows.org/wp-content/userfiles/Leverage_Points.pdf. Accessed 22 Feb 2022

Meadows DH (2008) Thinking in systems: a primer. Chelsea Green Publishing, London

Merleau-Ponty M (1962) The phenomenology of perception. (Colin Smith, Trans.). London: Routledge \& Kegan Paul. (Original work published 1962)

Merleau-Ponty N (1964) The primacy of perception. Northwestern University Press, Evanston, IL

Morton TA, Rabinovich A, Marshall D, Bretschneider P (2011) The future that may (or may not) come: how framing changes responses to uncertainty in climate change communications. Glob Environ Chang 21:103-109. https://doi.org/10.1016/j.gloenvcha.2010.09.013

Moser S, Dilling L (2011) Communicating climate change: closing the science-action gap, In: Dryzek JS, Norgaard, R.B., Schlosberg, D. (2011) The Oxford Handbook of Climate Change and Society. Oxford University Press, Oxford

Nelson MK, Shilling D (2021) Traditional ecological knowledge. Cambridge University Press

Norgaard KM (2011) Living in denial: climate change, emotions, and everyday life. MIT Press

Nortenergy. (2021) 'Storm strength from Shetland'. Polycrub. https://www.polycrub.co.uk/. Accessed 22 Feb 2022

O'Brien K, Wolf J (2010) A values-based approach to vulnerability and adaptation to climate change. WIREs. 1(2):232-242. https://doi.org/10.1002/wcc.30

Oram R, Adderley WP (2011) Innse Gall:culture and environment on a Norse frontier in the Scottish Western Isles. In: The Norwegian Domination and the Norse World, C. 1100-c.1400. Tapir Academic Press. https://dspace.stir.ac.uk/bitstream/1893/3258/1/Re\%20Innse\%20Gall\%20(Roros).pdf. Accessed 22 Feb 2022

Rana S, Ávila-García D, Dib V, Familia L, Gerhardinger LC, Martin E, Martins PI, Pompeu J, Selomane O, Tauli JI, Tran DHT, Valle M, von Below J, Pereira LM (2020) The voices of youth in envisioning positive futures for nature and people. Ecosyst People 16(1):326-344. https://doi.org/10.1080/ 26395916.2020.1821095

Raymond CM, Kaaronen R, Giusti M, Linder N, Barthel S (2021) Engaging with the pragmatics of relational thinking leverage points and transformations - Reply to West et al. Ecosyst People 17(1):1-5. https://doi.org/10.1080/26395916.2020.1867645

Reid H, Cannon T, Berger R, Alan MHS, Milligan A (2009) Community-based adaptation to climate change: an overview. In: Reid H, Cannon T, Berger R, Alam M, Ashley H, Kenton N, Milligan A (eds) Community-based adaptation to climate change participatory learning and action. international institute forenvironment and development. Earthprint Ltd., Stevenage, pp 11-33

Milligan, A. (Eds.) Community-based adaptation to climate change participatory learning and action. International Institute for Environment and Development. Earthprint Ltd. Stevenage, UK. https:// pubs.iied.org/pdfs/G02608.pdf

Ritchie W (2011) Machair development and chronology in the Uists and adjacent islands. Proceedings of the Royal Society of Edinburgh. Section B. Biol Sci 77:107-122. https://doi.org/10.1017/S0269 727000012677

Ross A (2018). The finitude of the world: economy and ecology. Theory \& Event 21(4): 776-803. https://www.muse.jhu.edu/article/707010 
Scharmer CO (2009) Theory U: leading from the future as it emerges. Berret- Koehler, Inc., San Franciscohttps://questionnaire.app.co.id/portal.nsf/78d9e44a4f6c67d9472571f80017eaa8/001989b230 d24d32472573f4000ac595/\$FILE/Theory\%20U.pdf

Scharmer CO, Kaufer K (2015) Awareness-based action research: catching social reality creation in flight. In: Bradbury H (ed) The SAGE handbook of action research. Sage Publications, London, pp 199-210

Sims R, Barton B, Bennett P, Isaacs N, Kerr S, Leaver J, Reisinger A, Stephenson J (2016) Transition to a low-carbon economy for New Zealand. Royal Society of New Zealand, Wellington. https://royal society.org.nz/assets/documents/Report-Transition-to-Low-Carbon-Economy-for-NZ.pdf. Accessed $22 \mathrm{Feb} 2022$

St. Martin K (2009) Towards a cartography of the commons: constituting the political and economic possibilities of place. Prof Geogr 61(4):493-507. https://doi.org/10.1080/00330120903143482

The Carbon Literacy Project (2021) The carbon literacy trust. https://www.manchesterclimate.com/invol ved/the-carbon-literacy-project. Accessed 22 Feb 2022

Varela FJ, Thompson E, Rosch E (1991) The embodied mind: cognitive science and human experience. MIT Press Cambridge, Mass

Weber A, and Kurt H. 2016. The enlivenment manifesto: politics and poetics in the anthropocene. Kosmos J Glob Transform Spring I Summer. https://www.kosmosjournal.org/article/the-enlivenmentmanifesto-politics-and-poetics-in-the-anthropocene/

Wenger E (1998) Communities of practice: learning, meaning, and identity. Cambridge University Press, NY

Wenger E, McDermott R, Snyder WM (2002) 'Seven principles for cultivating communities of practice'. In: Wenger E, McDermott R, Snyder WM (eds) Cultivating Communities of Practice: A Guide to Managing Knowledge. Harvard Business School Publishing, pp 49-64. https://www.clearwatervic. com.au/user-data/resource-files/7Principles_Community-of-Practice.pdf

Wenger-Trayner, E, \& B. (2015) Introduction to communities of practice: A brief overview of the concept and its uses. Available at: https://wenger-trayner.com/wp-content/uploads/2015/04/07-Brief-introducti on-to-communities-of-practice.pdf. Accessed 22 Feb 2022

West S, Haider LJ, Masterton V, Enqvist JP, Svedin U, Tengo M (2018) Stewardship, care and relational values. Curr Opin Environ Sustain 35:30-38. https://doi.org/10.1016/j.cosust.2018.10.008

West S, Jamila HL, Stålhammar S, Woroniecki S (2020) A relational turn for sustainability science? Relational Thinking, Leverage Points and Transformations, Ecosystems and People 16(1):304-325. https:// doi.org/10.1080/26395916.2020.1814417

Whitmarsh L (2011) Scepticism and uncertainty about climate change: dimensions, determinants and change over time. Glob Environ Chang 21:690-700. https://doi.org/10.1016/j.gloenvcha.2011.01.016

Whitmarsh L, O’Neill S, Lorenzoni I (2013) Public engagement with climate change: what do we know and where do we go from here? Int J Media Cultural Polit 9 (1): 7-25(19) https://doi.org/10.1386/macp.9. $1.7 \_1$

Whiteley CH (1969) II Epistemological Strategies Mind 18(309):25-34. https://doi.org/10.1093/mind/ LXXVIII.309.25

Wibeck V, Linnér BO, Alves M, Asplund T, Bohman A, Boykoff MT, Feetham PM, Huang Y, Nascimento J, Rich J, Rocha CY, Vaccarino F, Xian S (2019) Stories of transformation: a cross-country focus group study on sustainable development and societal change. Sustain 11:2427. https://doi.org/10.3390/ su11082427

Wilcox, H.N. (2009) Embodied ways of knowing, pedagogies, and social justice: inclusive science and beyond. NWSA Journal. 21(2): 104-120. https://www.jstor.org/stable/20628176

Woiwode C, Schäpke N, Bina O et al (2021) Inner transformation to sustainability as a deep leverage point: fostering new avenues for change through dialogue and reflection. Sustain Sci 16:841-858. https://doi. org/10.1007/s11625-020-00882-y

Publisher's note Springer Nature remains neutral with regard to jurisdictional claims in published maps and institutional affiliations.

Pre-submission archiving statement This paper has not been placed in any archive or on my personal website. 